\title{
Stories in the agenda: a Narrative Policy Framework study
}

\author{
Damasio Duval Rodrigues Neto ${ }^{1}$ \\ Márcio Barcelos 1 \\ ${ }^{1}$ Universidade Federal de Pelotas / Departamento de Administração da Faculdade de Administração e Turismo, Pelotas / RS - \\ Brazil
}

This study applies the "Narrative Policy Framework" (NPF) to the affirmative action policy process of the Federal University of Pelotas (UFPEL) and proposes theoretical intersection between the NPF and agenda setting literature, seeking to find out the role of policy narratives in policy processes. NPF is an empiric-oriented framework that posits that the policy-makers' stories have generalizable components and are built and crafted in accordance to their ideas. These are policy narratives, and are at the center of the policy process. By analyzing formulation stages of public policy and referring to ideas and narratives, the NPF refers to the agenda setting literature and provides means for empirical research of agenda setting concepts. The study undertook analysis of regulatory outputs and semi-structured interviews. Findings indicate that policy narratives have affected institutional regulatory outputs regarding UFPel's affirmative action policies.

Keywords: narrative policy framework; policy analysis; agenda setting; affirmative action.

\section{Histórias na agenda: uma aplicação do "Narrative Policy Framework"}

Este artigo aplica o "Narrative Policy Framework" (NPF) ao processo de produção das políticas de ações afirmativas da Universidade Federal de Pelotas (UFPEL) e propõe especificação de intersecção teórica entre o NPF e a literatura sobre formação de agenda, visando responder questões sobre o papel das narrativas em processos de produção de políticas públicas. O NPF é uma abordagem de orientação empírica que propõe que as histórias que os atores do processo de produção de políticas públicas utilizam têm componentes generalizáveis e são criadas estrategicamente, de acordo com suas ideias e sistemas de crença. Essas histórias são chamadas "narrativas de política" e são consideradas parte central dos processos de políticas públicas. Ao analisar a formulação de políticas públicas e abordar o papel das ideias e das narrativas, o NPF dialoga diretamente com a abordagem da formação de agenda e provê meios para a pesquisa empírica de conceitos desenvolvidos nesta literatura. A metodologia para este estudo utiliza análise de documentos regulatórios oficiais e entrevistas semiestruturadas. Resultados indicam que narrativas de política foram utilizadas e influenciaram a regulamentação das políticas de ações afirmativas da UFPel.

Palavras-chave: narrative policy framework; análise de políticas públicas; formação de agenda; ações afirmativas.

\section{Historias en la agenda: un estudio del Narrative Policy Framework}

Este artículo aplica el Narrative Policy Framework (NPF) al proceso de producción de políticas de acciones afirmativas de la Universidad Federal de Pelotas (UFPEL) y propone avances teóricos que exploran la intersección entre el NPF y la literatura sobre formación de agenda. El NPF es un enfoque orientado empíricamente que propone que las historias que utilizan los actores en el proceso de formulación de políticas tienen componentes generalizables y se crean estratégicamente de acuerdo con sus ideas y sistemas de creencias. Estas historias se llaman "narrativas de política" y se consideran una parte central de los procesos de políticas públicas. Al analizar la formulación de políticas públicas y abordar el papel de las ideas y narrativas, el NPF dialoga directamente con la literatura sobre la formación de la agenda y proporciona medios para la investigación empírica de conceptos desarrollados en este enfoque. La metodología para este estudio utiliza análisis de documentos reglamentarios y entrevistas semiestructuradas. Los resultados indican que se utilizaron narrativas de políticas e influyeron en la regulación de las políticas de acciones afirmativas de la UFPEL.

Palabras clave: narrative policy framework; análisis de políticas; formación de agenda; acciones afirmativas. 


\section{INTRODUCTION}

Scholars and researchers in the field of policy analysis have developed, since the early 2000's, the "Narrative Policy Framework" (NPF), an empirical approach to narrative studies in public policy research. This framework presents the concept of policy narratives which are the stories that policy makers utilize strategically to influence the policy process. The NPF's goal is to analyze the impact of these narratives on policy outputs (O'Leary, Borland, Stockwell, \& MacDonald, 2017).

In this article, this framework is applied to a case study that investigates the role of narratives in policy making within an organization. Articulated with well known theories of the policy process such as Kingdon's ([1984] 2014) and Baumgartner \& Jones' (1993), the NPF functions as a research platform to develop knowledge at the overlap between public policy making in the broad setting of the government and the translation of a broader policy regulation into a policy at the local level (Weible \& Carter, 2017; Weible \& Schlager, 2014). The case study under analysis is that of the construction of the affirmative action policy issue at Federal University of Pelotas (UFPel), in southern Brazil. UFPel is one of the largest universities in the state of Rio Grande do Sul. Considering students, faculty members and staff, the UFPel community is made of more than 25,000 people ${ }^{1}$. The city of Pelotas is one of the largest in the state of Rio Grande do Sul2, but the University's budget is higher than that of the city hall. Thus, decision making in an organization this size, even though it is not a public policy per se, can be analyzed as a complex process, where there are conflicts among different beliefs, argumentative disputes and construction of narratives.

In this sense, taking UFPel as a unit of analysis can be useful to understand the role of narratives in a decision process, specifically on the issue of ethnic-racial based affirmative action. The city of Pelotas has a history linked to the past of Brazilian slavery. Throughout the 19th century the city developed as one of the most important in Brazil based on the production of a specific food that was made by enslaved labor: salted dried meat, called in Portuguese "charque" (beef jerky). Until today, one of the most important tourist attractions in the city are the "charqueadas", the luxurious 19th century estates of the "Charque Barons". These echoes of a slavery past still generate controversy in the city ${ }^{3}$. So, the decision to adopt an affirmative action policy at UFPel constitutes a relevant case due to the conflict of institutional friction on the one hand, and a marked advancement of inclusive policies on the other, which we hypothesize was made possible by the development of narratives. The main goal of this article is to examine the role and impact of narratives in the decision making process at UFPel.

Agenda setting revolves around the definition of certain alternatives and exclusion of others in decision making processes. Undoubtedly, strategic use of narratives is a way of influencing these processes. Taking this assumption, this article analyzes the activity of an organized coalition in

\footnotetext{
${ }^{1}$ Retrieved fromhttp://portal.ufpel.edu.br

${ }^{2}$ Pelotas is the fourth largest city in Rio Grande do Sul, with a population of over 340,000 inhabitants.

${ }^{3}$ The classic investigation "Capitalismo e Escravidão no Brasil Meridional” (Capitalism and Slavery in Southern Brazil) by the sociologist and former brazilian president Fernando Henrique Cardoso was carried out taking the case of Pelotas as an empirical basis (Cardoso, 2003).
} 
framing a policy issue in a complex organization such as a federal university in Brazil. We seek to study the construction of a policy issue, its rise to the agenda and its transformation into an institutional policy, looking to answer the question "What is the role of narratives in this process?" By analyzing a case study within an organization we seek to contribute in advancing knowledge about the policy process in a public institution, exploring the overlap between research fields that have shared common developments such as a theoretical turn towards a social constructionist understanding of cognition and communication processes (March \& Simon, 1958; Simon, 1979). Both the public policy process per se and the decision making process within an organization such as a public university are permeated by discourses that reflect people's ideas. As such, we identify similarities between institutional decision making in a public organization and the broader public policy process (Bozeman, 2013; Rodrigues, Barcelos \& Pinto, 2019). Closer examination of the institutional policy making process is based on three observations: 1 ) assessment of the university as a policy environment similar to the federal government (Kingdon 2014, pp. 84-86); 2) opportunity to advance knowledge about unspecified stages of the policy process (Bozeman, 2013; Weible \& Carter, 2017); 3) opportunity to advance research about the NPF, which is still scarce in Brazil.

Much has been studied about the policy process as a whole but specific studies about the intricacies of public policy application in the organization level remain relatively unexplored (Weible \& Carter, 2017). Therefore, analyzing the process of transformation of the broader affirmative action regulation into a policy at the institutional level will provide knowledge about an unspecified stage of the policy process. As such, this article presents an exploratory study on the impact of narratives in the process of affirmative action policy making at Federal University of Pelotas (UFPel).

Beyond this introduction and its conclusion, this article features a brief review of combining aspects of agenda setting and NPF theory; an overview of NPF, emphasizing central aspects that were utilized in this study; a methodology section; a summary of the affirmative action policy making process at Federal University of Pelotas; and an analysis and discussion section.

\section{AGENDA SETTING, IDEAS AND NARRATIVES: CONTEXT AND COMBINING ASPECTS}

There is a long tradition in Public Policy studies consisting of analysis of pre-decisional procedures, a field that gains traction from Shattschneider's (1960) insights about scope of conflict and mobilization of bias. Pioneering studies as well as contemporary agenda setting research share a concern with conflicted processes in which certain policy issues command attention in public spaces, while other issues are left out from it.

Developments of theories of the policy process that focus on the construction of policy issues advanced significantly in the 1980's and 1990's. In 1984 John Kingdon presented the "Multiple Streams Approach" (MSA), an agenda setting theory developed from the assumption that "ideas matter" in the policy process. In his introduction, Kingdon (2014, p. 1) draws attention to the power of "an idea whose time has come", underlining the conflicted, dynamic nature of decision making in policy processes. MSA theory underscores the role of the policy entrepreneurs, actors that explore policy windows that, when open, enable agenda access to certain issues. In Kingdon's theory, a policy 
window is a key moment in time when three relatively independent streams converge: 1 ) a problem is recognized; 2) a policy solution is technically viable, and 3) there is political acceptance to the policy solution (Kingdon [1984], 2014).

Less than a decade after Kingdon's seminal work, Baumgartner and Jones (1993) presented the "Punctuated Equilibrium Theory" (PET) which also focuses on agenda setting and emphasizes the role of ideas and beliefs in the policy process. A key concept in PET is the "policy image", which synthesizes both the value of ideas and strategic framing of policy issues in favorable portraits related to the ideas that are being pushed by the policy makers - "How a policy is understood and discussed is its policy image" (Baumgartner \& Jones, 1993, p. 25). The concept implies that there are several possible framings to an issue and that ascendance of a given understanding can be built through argumentation. Persuasion performs a central role in the framing of images that are constructed by symbolic representations and subtleties of language. This argumentative nature highlights the assumption that policy decisions, whether within an organization (as in the case of this study) or a public policy per se, are socially constructed. In the words of Majone (1989, p. 1), "public policies are made of language. Whether in written or oral form, argument is central in all stages of the policy process".

Agenda setting refers to highlighting certain aspects while deliberately looking past others. Social conditions do not generate policy solutions by themselves, instead they are given life in processes of argumentation and image making. Policy requires persuasion, convincing about a situation being problematic, which is often performed in the form of a story that uses causal connections in order to demonstrate that a certain condition is not inherent to nature, but it is within the realm of human control and thus can be subject to action in form of public policy. Connection between the problem and the proposed solution is demonstrated in strategically crafted stories that link the problem to a solution through causal mechanisms that assign blame over a problematic situation (Stone, 1989, 2012). For public policy, a problem is a situation that was recognized as subject to action (Kingdon, 2014, pp. 109-115; Stone, 1989, pp. 282-289).

Thus, literature has pointed out how much agendas are significantly impacted by the ways how policy actors define, interpret and process reality, shaping social conditions into problems that must be subject to policy solutions. Due to the accepted importance of argumentation, it becomes important to analyze specifically and systematically the role of narratives in the policy process. Concepts such as "policy image" (Baumgartner \& Jones, 1993), "problem definition" (Rochefort \& Cobb, 1994) and "causal stories" (Stone, 1989) relate to each other in the sense that they all speak to the framing of policy issues in terms that are congruent to the ideas and beliefs of determined policy actors.

This article, then, focuses on strategic issue portraits that are performed by policymakers, linking such frameworks of agenda setting and Narrative Policy Framework. Narratives have traditionally been a part of agenda setting literature as they undeniably interfere with people's perception over policy issues. Discourses, interpretations and symbolic representations perform a substantial role in problem definition and public policy outputs reflect more on argumentative processes than formal technique application. Literature gives to ideas a fundamental role in policy 
making and policy makers' ideas are commonly organized in strategically crafted narratives that permeate the main theories of the policy process. Peterson $(2018$, p. 837) suggests that "policy images are often policy narratives" and Peterson and Jones (2016) identify similarity between the policy image concept and problem definition, pointing out that the latter "(allows) for policy action" (p. 114) which is basically what policy narratives aspire to. Policy narratives typically have a dramatic plot that is built by highlighting certain aspects of the narrative and "adding color" to information (Peterson, 2018). According to Stone (1989), the main form of problem definition in policy making is to assign blame over problems, which is done in stories that explore four causal mechanisms: mechanical cause, intentional cause, accidental cause, and inadvertent cause. These mechanisms refer to the specific causal connection between the problem and the solution. Stone (1989) calls the accidental and intentional cause mechanisms "strong positions" that place conditions either within the sheer accidental or within complete human control, while the mechanical and inadvertent cause mechanisms express "mixed positions" as they employ diffuse strategies, blaming mechanical failure or social/institutional/structural causes instead of a determined person or group (Stone, 1989, pp. 283-289). NPF research has often pointed to or applied Stone's typology as a tool for systematic study of narrative strategies (Jones \& McBeth, 2010; Shanahan, et al., 2013; Shanahan, Adams, Jones, \& McBeth, 2014; Zanocco, Song, \& Jones, 2018).

However, NPF and agenda setting are not intrinsically interwoven, which calls for specification of intersection among these frameworks. Peterson and Jones (2016) and Weible and Schlager (2014) attest to NPF's potential as a bridge for development of narrative studies within other frameworks and theories of the policy process. Here we focus on common understanding between the concepts of policy image, problem definition and policy narrative. We argue that plots in policy narratives can be studied as examples of policy image making or problem definition, considering that causal connections that are highlighted in crafting a policy image, according to Baumgartner and Jones (1993, p. 26) "a mixture of empirical information and emotive appeals" - and in problem definition, according to Stone (1989, p. 282) - "a process of image making, where the images have to do fundamentally with attributing cause, blame, and responsibility" - are consistent with NPF theory description of the structural element of the plot.

\section{THE NARRATIVE POLICY FRAMEWORK: AN OVERVIEW}

Since the late 1980's several authors have pointed out the importance of studying the role of narratives in the policy process (Fischer \& Forester, 1993; Hajer, 1993; Majone, 1989; Stone, 1989). This field was highly marked for its opposition to the more traditional frameworks of Political Science and Policy Analysis, both criticized for their positivist approach (Fischer, 2003, 2007). This brand of literature was named by Fischer (2006) as "postpositivist". It is important, then, to state that the NPF stems from and dialogues with this postpositivist framework (Jones \& Radaelli, 2015). However, if it is rooted on interpretative epistemology, its latter developments, especially from a methodological standpoint, followed another path. 
Due to space limitations, we present a NPF overview focusing on elements that are directly studied. More comprehensive reviews can be found in Jones and McBeth (2010) and Shanahan, Jones, and McBeth (2018). In summary, NPF theory postulates that policy narratives are "stories with a temporal sequence of events unfolding in a plot that is populated by dramatic moments, symbols, and archetypal characters, culminating in a moral to the story" (Jones \& McBeth, 2010, p. 329). According to NPF literature, policy narrative components are the structural elements cited in the concept above (setting, plot, characters, and moral to the story) and the narrative strategies that constitute the content of each policy narrative.

Setting is the context where a narrative takes place. It can be a geographical or institutional space, a time period or even a controversy in itself. Plot is the story that connects structural elements of a narrative, typically including a dramatic arc. Characters are the protagonists of the story, typically identified as heroes, villains and victims. And moral to the story is the conclusion to the narrative, which presents an action to be made in the form of a policy proposal or at least a mention to a public policy (Jones, 2018; Jones \& McBeth, 2010; Shanahan et al., 2018).

Narrative content is much more difficult to be typified, as different narratives might feature completely different content. As stated by Jones (2018), though, NPF relies on the notion of bounded relativity, which postulates that narrative composition is not absolutely unpredictable, but relative to strategies of causation that reflect ideas and belief systems. The most developed narrative strategy studied in NPF literature is the usage of causal mechanisms, derived from Stone's (1989) typology of causal stories (see p. 5). An important study of causal mechanisms in NPF is that of Shanahan, Jones, McBeth, and Lane (2014), which finds evidence that "causal mechanisms, as a whole, do not affect policy opinions, but, rather, the specific kind of casual mechanism employed does" (p. 82).

Another important aspect of NPF is the three levels of analysis, which refer to the scope of the framework's application. Micro level refers to narrative influence on individuals; meso level examines narrative influence on coalitions; and macro level examines narratives in broad cultural and institutional context. Again, due to research design ${ }^{4}$, we focus on the meso level which is the most developed and is especially amenable to intersection with agenda setting concepts (Peterson \& Jones, 2016). Much of what agenda setting theories focus on is coalition activity in the "policy subsystems" environment, which is the subject itself of the meso level. As hinted before, coalitions involved in policy making do not simply watch from the outside; they actively try to influence the outputs of decision making, which is made through several strategies studied in agenda setting literature such as issue expansion and blame shifting. Shanahan, Raile, French, and McEvoy (2018) assert that NPF meso level research historically "has relied on emphasis framing research that uses case studies to identify issue-specific frames" (p. 924), which is our approach here.

\footnotetext{
${ }^{4}$ Comprehensive reviews and empirical applications of the NPF levels of analysis can be found in Jones and McBeth (2010, pp. 343-346), Shanahan et al (2013, pp. 456-457), Kirkpatrick and Stouten borough (2018) - on micro level research -, Ney (2014) - on connecting meso and macro levels - and Peterson (2018) - on innovations to the macro level.
} 
An alternative development of NPF, designed to circumvent limitations to conduction of quantitative research, is the Qualitative NPF by Gray and Jones (2016). They propose a conceptual finetuning and incorporation of qualitative epistemology, replacing quantitative standards for widely recognized qualitative standards, namely "credibility, transferability, dependability, and confirmability" (Gray \& Jones, 2016, pp. 194-199).

This was a brief summary of the NPF, intended to acquaint this framework with Brazilian policy analysis field and more specifically with national agenda setting studies. Looking to build on theoretical intersection of NPF with agenda setting concepts, we apply NPF theory to an agenda setting process in a federal university. The methodology for such study is detailed next.

\section{METHODOLOGY}

Returning to the main purpose of this paper: it is to analyze the role of narratives in a given course of action that resulted in the adoption of affirmative action policies at Federal University of Pelotas. At this moment it is not possible to cover the entire process. That was done in a broader research, a Master's thesis from which this article is a follow up study (Rodrigues, 2018). This previous research and this paper are both based on within-case approach, following the perspective developed by scholars such as George and Bennett (2005) and Beach and Pedersen (2016). Therefore we define "... a 'case' as an instance of a causal process playing out." (Beach \& Pedersen, 2016, p. 5). In this sense, UFPel is taken as an unity of analysis to observe the role of narratives in a policy decision.

Methodological procedures performed in this study apply content analysis and employ the Qualitative NPF (Gray \& Jones, 2016). Content analysis was performed through coding, following Shanahan et al.s (2018) guidelines and codebook. Database consists of documents and semi-structured interviews conducted on research of the affirmative action policy process at UFPel. Even though interviews were not conducted with the specific purpose of performing a NPF study, theoretical intersection between agenda setting and NPF concepts is evident as all informants tell stories structured as narratives. What this study aims to confirm is if these narratives fit into the stricter "policy narrative" concept as developed in NPF and what impact stories had on regulatory outputs. This is performed by comparison of stories to NPF theory and of policy narratives identified to official outputs.

Content from all documents and interview transcripts was carefully read and each paragraph was coded in specific sheets where characters, plot, moral to the story and the identified narrative strategies were marked. Based on coding results, a main narrative from each data source was identified. Overall, 162 paragraphs and six interview transcripts were coded. Only components explicitly cited were considered. Plots and narrative strategies were coded according to Shanahan et al.'s (2018) codebook which presents five common plots ("Story of Decline", "Stymied Progress", "Change Is Only an Illusion", "Story of Helplessness and Control" and "Conspiracy") and to Stone's $(1989,2012)$ four causal mechanisms which are commonly utilized in NPF as narrative strategies templates. 
In the following phase, results were compared to UFPel's affirmative action regulatory outputs. Database for this task includes contextual information, that is, documents and interview content; the claims presented in these documents and interviews; and the regulatory outputs. Documents include official minutes of UFPel's academic councils meetings as well as archive documents obtained by the authors during research. The regulatory outputs analyzed are UFPel's official documents that regulate ethnic-racial based affirmative action policies. These include: UFPel's Conselho Universitário - CONSUN (University Council) Resolution 06, 2012; UFPel's Conselho Coordenador de Ensino, Pesquisa e Extensão - COCEPE (University Extension, Research and Teaching Coordinating Council) Resolution 15, 2015; CONSUN Resolution 05, 2017; and CONSUN Resolution 16, 2017, retrieved from https://wp.ufpel.edu.br/scs/.

These policy outputs regulate UFPel's quota system at the undergraduate level, specific entry program for indigenous and "quilombola" students, quota system at the graduate program level and student permanence policy, respectively. These are all UFPel's ethnic and racial-based affirmative action policies from the period between the years of 2012-2017. These official decisions are subject to analysis in this study but obviously, policy making does not start with official regulation. Rodrigues's (2018) research covers pre-decisional stages of the process, tracing it back to nearly twenty years before UFPel applied its first affirmative action policy. Regulatory outputs from the years 2012-2017 are analyzed as this is the period when ethnic and racial based affirmative action policies were implemented in the University.

As stated above, interviews selected for this study were not conducted specifically for NPF-based study, but for agenda setting analysis. Results that confirm the presence of policy narratives will serve to further support theoretical intersection between these frameworks. Informants are restricted to six policy entrepreneurs who were involved in the affirmative action policy process at UFPel. We emphasize that this is an exploratory study and results are not meant to lead to absolute conclusions about NPF application. Still, we do believe this study is in accordance with qualitative research standards such as credibility, transferability, dependability and confirmability.

\section{DEFINITION OF A POLICY PROBLEM: CONTEXTUALIZING UFPEL'S DECISION MAKING PROCESS}

Rodrigues (2018) and Rosa, Nunes, and Larré (2017) perform comprehensive descriptions of the policy making process of affirmative action policies at Federal University of Pelotas (UFPel). The latter analyze institutionalization of affirmative action policies in the University and the earlier studies the process of agenda setting, concluding that stories told by the actors involved in the process were substantial in problem definition of the issue.

In the context of gradual inclusion of issues related to racial equality in the government agenda, in August, 2012 Brazilian congress passed federal law 12.711, 2012, defining a four year schedule for public universities to fully implement a quotas system, but UFPel applied the full percentage stated in the law by 2014 .

\footnotetext{
${ }^{5}$ Remnants of "quilombola" communities, characterized according to self-attributed criteria: historical path, specific territorial relationships, black ancestry and resistance to slavery (Decree 4.887, 2003, Brazilian Presidency. Retrieved from http://www.planalto.gov.br/ccivil_03/ decreto/2003/D4887.htm
} 
Prior to law 12.711, 2012, the affirmative action issue as a whole was slowly inserted into the federal government's agenda. Ethnic-racial quota system in public universities first became a national issue in the early 2000's when the state of Rio de Janeiro passed state law 3.708, 2001. State University of Rio de Janeiro (UERJ) became one of the first public universities in Brazil to experience tensions resulting from affirmative action but aside from top-bottom implementation such as in the case of Rio de Janeiro, pioneering autonomous policies were implemented by Bahia State University (UNEB) and Brasília University (UnB) (Santos, 2012). Only almost a decade after the first experiences, resulting both from a long tradition of social pressure and from Partido dos Trabalhadores' (PT)/"Workers Party" (at the helm of the Executive branch from 2003-2016) increasing recognition of the racial equality issue in the government's agenda (Lima, 2010), Congress approved law 12.711, 2012, which, while an important landmark for ethnic-racial based affirmative action policy, applies in the first place social criteria, reserving $50 \%$ of entries at undergraduate level in federal public universities for students from public schools, and only secondarily ethnic-racial criteria, reserving a given percentage of the first cut for black and indigenous students (percentage depends on each region census results).

In general, the 1988 Federal Constitution represents an embryonic landmark for the recognition of the racial equality issue in Brazil but further approximation between black social movements and the federal government started in the second half of the 1990's. While during President Fernando Henrique Cardoso's tenure (1995-2002) the issue was recognized, actual redistributive policies were not implemented, a setting that was advanced under the Workers Party's (PT) administration, when public policy design was impacted by insertion of racial issues in the formal structure of the federal government, culminating with law 12.711, 2012 (Lima, 2010).

Both the federal process and the specific case of UFPel exist in a setting where institutions by themselves are not likely to implement redistributive policies that affect the status quo and expose their own social biases. Rosa, Nunes, and Larré (2017) describe the slow process of institutionalization of affirmative action policies and the setting where it took place, citing "institutional racism" (p. 228) that was still present at UFPel at the time of their writing. In the process of advancing the affirmative action issue to the list of issues seriously considered by the decision makers of the University, students' movements were trying to raise the racial issue throughout the latter half of the 2000's as debates about affirmative action policies in universities were brought up nationally. According to Rodrigues's (2018) research informants tell that before the event of law 12.711,2012, this issue was ignored by University authorities, stating that social movements and especially students' pressure must be recognized as actual inducers of ethnic-racial based policies and their specific design. More than simply applying federal law, UFPel was pressured into acting more decisively, deciding on increased quota percentages starting in 2013 and implementing autonomous policies afterwards.

Even though the city of Pelotas has a rich history of cultural and political activism by the black social movement (Ávila \& Oliveira, 2019), ethnic-racial minorities were virtually non-present at the local University previously to the implementation of affirmative action policies. The focal point of this case study is how the narratives presented by local actors had an impact in breaking 
institutional bias and inertia and promoted the rise of a previously ignored issue to the agenda of a public organization. The social condition of inequality in itself did not become worse in the period analyzed; then how and why did the affirmative action policy issue rise to the agenda? We hypothesize that stories crafted by representatives of ethnic-racial minorities brought attention to the issue and connected the social condition (the problem) to affirmative action policies (the solution), at a time when the issue was politically viable due to the federal law. Not only UFPel adopted the broader policy but it assumed a deeper role in promoting autonomous policies such as affirmative action policies at graduate program level and special entrance system for indigenous and "quilombolas".

In accordance with agenda setting literature such as Baumgartner and Jones (1993), Kingdon (2014) and Stone $(1989,2012)$, it is argued here that policy image, timing and causal connections played fundamental roles in promoting agenda access to the affirmative action issue. Analyzing previous history, it is unlikely that UFPel would have adopted affirmative action policies other than what was strictly defined by law. Representatives of different minority groups promoted issue expansion at the time when affirmative action policies were subject to national attention, framed a favorable policy image that portrayed ethnic-racial minorities as victims of social inequality and connected this problem to the aforementioned policy solution, blaming a broad socioeconomic context as the villain. This case study is specially relevant to the examination of the role of narratives in policy making because previous research indicates that stories told by the actors involved played a significant role in advancing a policy issue that otherwise would not have been subject of attention by decision makers (Rodrigues, 2018; Rosa, Nunes, \& Larré, 2017); and to broader policy research because it constitutes a possible innovation to the study of narratives and to the study of an unspecified piece of public policy processes - the transformation of a general policy regulation into an institutional policy at the local level (Weible \& Carter, 2017).

The broader "Social quotas law" determined a reserve of at least $12,5 \%$ of openings for affirmative action entrances in 2013 but UFPel adopted the $40 \%$ share that was submitted by proponents of the affirmative action issue. The venue for institutional decision making in this instance is CONSUN which is composed by representatives of several groups from within the University and civil society. Advocates of affirmative action policies successfully put forward a policy proposal of $40 \%$ reserve based on the story that highlighted the role of black people in the history of the city of Pelotas and all the socioeconomic disadvantages that excluded ethnich and racial minorities from spaces like public universities. The other venue of decision making is COCEPE which contains only representatives from within the institution and decides on more specific demands such as autonomous policies that were submitted in the following years. The sequence of policies implemented and the content of regulatory outputs suggest that the affirmative action issue was subject to a wide institutional policy process that was sustained by stories told by the policy advocates. Not all requests resulted in actual institutional policies but the political window functioned as a scenario for debate that was taken advantage of by the policy proponents and resulted in a wide process whose results include advancement of a relevant array of affirmative action policies. 
Rodrigues's (2018) research applied agenda setting concepts to analyze the aforementioned process and identified that several of these policies stemmed from narratives developed by members of the local black social movement and other actors that joined their coalition. The author identifies an almost unanimous framing of the affirmative action issue as a matter of reparation of past injustices. The "reparation framing" relied on the causal story that connects lack of black representation in higher education to the slavery period and its consequences on the black people's population. This narrative was composed both by empirical information - data that showcase disproportion between shares of black people in the overall population and shares of black people that access higher education - and emotional tone - stories of poverty, lack of opportunities and fight against the system. These stories helped engage previously apathetic groups such as professors and administrative staff from the university, who joined the coalition that demanded social justice at UFPel.

Representatives of indigenous people's interests joined the black movement and embraced the "reparation framing". The head of the students' policies department at the time championed the indigenous cause in the institutional venue (COCEPE) employing a similar narrative strategy, defending that Brazilian society has a debt with indigenous people and stating that if public universities do not open their doors for them, they would be forever excluded from that environment. He also argued that because of their different culture and lifestyle both indigenous and "quilombolas" students were not on equal grounds to run for a spot at a public university against urban candidates under the usual entry criteria.

Probably the most innovative policy implemented in this process was the 2017 decision of creating affirmative action policy at graduate program level. UFPel became one of the very first Brazilian universities to do so, accepting the narrative that presents the idea of "fair meritocracy" for graduate program level entry. According to the minutes of the proceedings, entrepreneurs claimed for the necessity of adopting new patterns of meritocracy and pointed to several examples of public and private institutions that were at that time implementing affirmative action policies. The regulatory output reserves $25 \%$ of graduate program level openings for blacks, "quilombolas", indigenous and people with disabilities.

In the highest profile case related to the racial issue at UFPel, fraud accusations presented by students led to the cancelation of 26 Medical School students' admissions due to the claim of false racial identification (Nunes, 2018). As a consequence of ensuing debates and following the lead of other universities, UFPel adopted more rigid, thorough identification criteria in 2016, creating a committee assigned to verify ethnic and racial characteristics of affirmative action entrance candidates (Rosa et al., 2017). Since then, this University passed different regulations regarding affirmative action policies.

Previous research about affirmative action policies institutional processes at UFPel suggest that the regular channels of decision making in this institution would not have been likely to expand the racial issue if proponents had not acted strategically telling stories that pushed these policies into the University's agenda. In the following section, we analyze these stories in light of Narrative Policy Framework theory. 


\section{RESULTS AND DISCUSSION: ANALYZING THE ROLE AND IMPACT OF NARRATIVES}

Finally, in this section, narratives utilized in UFPel's affirmative action policy process are analyzed and findings are discussed. First, we set out to demonstrate research alignment with NPF theoretical assumptions; after, we analyze narrative components. Basic NPF assumptions state that policy realities are socially constructed, variations to these constructions are relatively stable over time, policy narratives have specific, identifiable components, and operate at three interactive levels, and that narratives play a fundamental role in human cognition and communication (Jones, 2018; Shanahan et al., 2018). Other than the three levels of analysis which is a NPF specific characteristic, these assumptions are implied in agenda setting theories that hold similar understandings of individual cognition and information processing (Baumgartner \& Jones, 1993; Kingdon, 2014; Stone, 1989, 2012). The assumption of socially constructed realities and the presence of strategically crafted narratives in the policy process are examples of agenda setting literature developments that attest the suggestion that "ideas matter" in policy making and the NPF can provide specification of this notion.

Research questions coherent with NPF theory at the meso level are "How do groups construct policy narratives?" and "What is the effect of policy narratives in the policy process?", both of which ultimately help to understand how and why policies change. Since this is an exploratory case study, we focus on discussing these two general questions. Hypotheses that originated this research state that coalitions involved in UFPel's affirmative action policy process produced policy narratives and that these narratives influenced institutional regulatory outcomes. By following these preliminary steps we assure that this study is in proper alignment with NPF theory; over the next paragraphs, we analyze the narratives themselves.

Findings indicate that the policy narrative setting is the institutional and processual space in which affirmative action policies covered in this study were discussed at the time of their implementation by UFPel (2012-2017). Institutional venues include CONSUN and COCEPE. Policy proposals in the years of 2012 and 2013 were organized by the coalition named "Fórum Cotassim" which included civil society representatives, social and student movements and UFPel professors and administrative staff. In the final months of 2012, after law 12.711, 2012 was approved, this coalition pressured UFPel into taking a formal stance on how the policy would actually be implemented in this University. "Fórum Cotassim" gained support of some members of CONSUN and proposed a 40\% quota system at undergraduate level for 2013 entrance at the meeting of November, 13th, 2012. In the following years proposals were presented by institutional actors from within the University, in the case of special openings for indigenous and quilombola students, and by representatives of the black social movement in the case of graduate program student level affirmative action policies.

With federal law 12.711, 2012 regulating affirmative action in public universities in broader terms, debates at UFPel focused on how the policy would be applied. The "Fórum Cotassim" coalition acted as the hero that presented demands to University management and findings suggest that these demands would come to shape UFPel's affirmative action policies. Stories identified in this research are coherent with narratives developed by the black social movement in broader 
contexts such as nation wide debates as actors involved with the policy process at UFPel also act in other settings, as well as actors from other settings were involved with the local process at $\mathrm{UFPel}^{6}$. A small share of narratives feature a villain, identified in different instances as society, the State or universities, indicating that most universities in the country had not worked effectively to foster social inclusion. All narratives presented black people, indigenous and/or quilombola communities as victims of a socioeconomic context that excluded them from praised social spaces such as public universities.

The most common plot identified across all narratives was the "Story of Helplessness and Control", as narratives highlighted the long standing position of vulnerability of black people, indigenous and quilombolas within Brazilian society, a situation that during decades was considered as being insurmountable but that was finally being subject to change. All entrepreneurs interviewed told stories containing a dramatic arc describing consequences of slavery and economic segregation that still impact those populations and couple this problem to the affirmative action policy solution. The next common plot was the "Conspiracy" one, as a smaller portion of the database, that describes a story where a small group has controlled higher education access for their own benefit during most of Brazil's history.

Linked to those plots are the causal mechanisms that assign blame to the elite groups that benefit from that situation. The most common strategy was the inadvertent cause mechanism, stating that the situation of inequality of opportunities is resultant of neglect, carelessness and omission, thus not blaming villains directly. A considerable share of narratives features mechanical cause and intentional cause mechanisms. Mechanical cause states that unguided actions carried out indirectly produce consequences intended by those in control. Intervening agents do not have the specific goal of oppressing ethnic and racial minorities but regardless of their will, their actions are designed to perpetuate inequality; intentional cause states that purposeful actions carried out by specific actors cause the problem, consisting in this case of willful oppression and conspiracy, which was utilized scarcely among narratives.

Characters and moral to the story can be understood in straight forward fashion, but we identify more complexity in plot and strategies. Box 1 provides specific examples of narrative excerpts that were coded as determined types proposed in NPF theory. From these findings we speculate that the "Story of Helplessness and Control" plot can be theoretically linked to "mixed positions" causal mechanisms, the ones that don't consider consequences neither as purely accidental or consciously intended, while the "Conspiracy" plot can be linked to the "strong position" causal mechanism of intentional cause (Stone, 1989, pp. 284-285).

\footnotetext{
${ }^{6}$ e.g. Resolution 05, 2017 adopts narratives from Minute 03, 2017 (Retrieved from https://wp.ufpel.edu.br/scs/files/2017/04/ATA-03.2017CONSUN.pdf), when the president of the national institution EDUCAFRO (Retrieved from https://www.educafro.org.br/site/) was one of the representatives of the local black coalition.
} 


\begin{tabular}{|c|c|c|}
\hline Narrative & Plot & Strategy \\
\hline \multirow{3}{*}{$\begin{array}{c}\text { "I'd rather say there's been omission, in the } \\
\text { sense of not worrying with a more equal } \\
\text { society". }\end{array}$} & \multirow{4}{*}{$\begin{array}{l}\text { Story of Helplessness } \\
\text { and Control }\end{array}$} & \\
\hline & & Inadvertent cause \\
\hline & & \\
\hline $\begin{array}{l}\text { "Society and the State owe these } \\
\text { groups, because they've been historically } \\
\text { excluded". }\end{array}$ & & Mechanical cause \\
\hline $\begin{array}{l}\text { "This anomy state has always served the } \\
\text { ones that hold power, to utilize cheap } \\
\text { workforce, for electoral purposes...". }\end{array}$ & Conspiracy & Intentional cause \\
\hline
\end{tabular}

Source: Elaborated by the authors.

Comparison between narratives and regulatory outputs reveals that the stories told in the policy process affected and shaped UFPel affirmative action policies. When this University first applied affirmative action at undergraduate level, it followed "Fórum Cotassim" proposal of reserving 40\% of openings instead of following the minimum demanded by law.

The following box contains excerpts from Minute 06, 2012, from November, 13th, 2012, which describes discussions that occurred during CONSUN's meeting immediately prior to the decision making instance when UFPel's highest collegiate authority, the University Council, laid out details for the implementation of quotas system. This document registers that representatives of the social black movement presented an organized narrative portraying black people as the victims of socioeconomic structural disadvantages. The Minute also documents that several representatives from within the University gave their thoughts about the issue, both in favor and against the $40 \%$ proposal. Opposing narratives utilized an "impact framing", defending that the University was not prepared to welcome so many affirmative action students and one opposing actor labeled black people as "beneficiaries", a framing vehemently opposed by the black coalition. Eventually, CONSUN decided in favor of the $40 \%$ proposal, explicitly considering deliberations from this meeting (Box 2). 


Narrative
Regulatory output
"Several problems that black people face in our country...".
"We evidently live in a discriminatory society ... Poverty in
Brazil has color: it is black, predominantly".
"In regards to the quota system, we would like to work with
the maximum percentage (...)".
"Proposal is in accordance with the law and I pledge
everyone's sensibility ... thus propose that Pelotas have right
away at least 40\%...".

Source: Elaborated by the authors.

As for the creation of special openings for indigenous and quilombolas, the narrative presented University management itself as the hero if they approved such policy; the plot utilized a dramatic arc stating that if University did not grant special entrance opportunities for them, indigenous and quilombolas would not be able to access higher education. The regulatory output in reference (COCEPE Resolution 15,2015) cites these arguments and creates ten openings for indigenous and quilombolas, with specific entrance criteria (Box 3 ). 


\begin{tabular}{|c|c|}
\hline Narrative & Regulatory output \\
\hline $\begin{array}{l}\text { "If University does not adopt specific entrance criteria, it } \\
\text { will always keep a door shut for human and professional } \\
\text { development of this group". }\end{array}$ & $\begin{array}{c}\text { Considering the need to amplify UFPel affirmative action } \\
\text { scope and attesting a historical demand from social } \\
\text { movements. }\end{array}$ \\
\hline $\begin{array}{l}\text { "This would be one more action that showcases UFPel's great } \\
\text { commitment to the ... social inclusion of these communities } \\
\text { with which society has a historical debt". } \\
\text { "Fórum Cotassim postulates it is necessary to establish } \\
\text { specific criteria for the access and accompaniment of } \\
\text { indigenous, quilombolas and traditional community members } \\
\text { at UFPel". } \\
\text { "Without specific openings, we hardly would have students } \\
\text { coming from these communities". }\end{array}$ & $\begin{array}{l}\text { Considering the importance of creating alternative entrance } \\
\text { criteria for indigenous and quilombola students, whose culture } \\
\text { and lifestyle are different and may impair their participation in } \\
\text { selective processes such as ENEM. } \\
\text { Approves creation of ten specific openings for indigenous and } \\
\text { quilombola students. }\end{array}$ \\
\hline
\end{tabular}

Source: Elaborated by the authors.

In its most innovative affirmative action implemented so far, UFPel created a quotas system at the graduate program level, embracing narratives presented in the University Council by representatives of the black social movement. Stories documented in the official minute state that institutions from different areas were creating affirmative action policies and that Brazilian universities should adopt "new meritocracy standards". Interviews mention the lack of black representatives among professors and couple that situation to the presented solution. CONSUN Resolution 05, 2017 is the richest regulatory output for discussion here as it showcases institutional images not only referent to graduate program level policy but also to the "reparation framing", stating that affirmative action policies "are not concessions of the State" and that the University as a whole will benefit from promoting ethnic diversity (Box 4). 


\begin{tabular}{|c|c|}
\hline Narrative & Regulatory output \\
\hline $\begin{array}{l}\text { "Several University Councils of Brazilian institutions were not } \\
\text { open for new meritocracy standards". }\end{array}$ & $\begin{array}{l}\text { Considering that affirmative action policies in Brazil, } \\
\text { understood as measures that have the scope of reparation or } \\
\text { compensation of social inequality and racial discrimination, } \\
\text { are not concessions of the State. }\end{array}$ \\
\hline $\begin{array}{l}\text { "UFPel has thousands of professors, and we have a measly } \\
\text { percentage of black ones. This reality of invisibility of black } \\
\text { people in higher education faculty made us think, start } \\
\text { questioning ... How are we going to aspire to have black } \\
\text { professors if there are no blacks at the graduate program level?" }\end{array}$ & $\begin{array}{l}\text { Considering that undergraduate level affirmative action at } \\
\text { UFPel, accompanied by other experiences in universities across } \\
\text { Brazil since 2012, creates demand for further professional } \\
\text { and academic qualification, being important, thus, student } \\
\text { permanence policy at the graduate program level. }\end{array}$ \\
\hline $\begin{array}{l}\text { "University benefits with the presence of these people, it } \\
\text { becomes more complete, more diverse, richer". }\end{array}$ & $\begin{array}{l}\text { Considering that all UFPel Graduate Level Programs will } \\
\text { benefit academically from adopting affirmative policy that } \\
\text { favors ethnic and cultural diversity. }\end{array}$ \\
\hline
\end{tabular}

Source: Elaborated by the authors.

The last regulatory output discussed in this section is CONSUN Resolution 16, 2017 which regulates student permanence policy at the graduate program level. In this case, data available to this study does not provide as much indication that the regulatory output was influence by narratives as the previous documents. The student permanence issue was present throughout narratives in the documents and interviews analyzed, but the specific policy regulated is only mentioned in interviews conducted after its implementation, in which informants look back on the process (Box 5).

GRADUATE PROGRAM LEVEL AFFIRMATIVE ACTION STUDENT PERMANENCE POLICY

\begin{tabular}{|c|c|}
\hline Narrative & Regulatory output \\
\hline $\begin{array}{l}\text { "Due to their socioeconomic needs, all affirmative action } \\
\text { students must have priority to access student aid policies". }\end{array}$ & $\begin{array}{l}\text { Considering that affirmative action policies constitute a wide } \\
\text { process within higher education institutions, which equally } \\
\text { demands development of student permanence policies. }\end{array}$ \\
\hline $\begin{array}{l}\text { "I experienced difficulties to survive at the Graduate Program } \\
\text { level, because it's not enough to join, there's the xerox you } \\
\text { have to pay, the field research you have to make...". }\end{array}$ & $\begin{array}{l}\text { Considering that the statutory commitment of education } \\
\text { democratization in which refers to equal opportunities of access } \\
\text { and continuity must attend to graduate program level students. } \\
\text { Approves student permanence policy for affirmative action } \\
\text { students at Graduate Program level. }\end{array}$ \\
\hline
\end{tabular}

Source: Elaborated by the authors. 
Even though results displayed in Box 5 showcase less evidence that narratives influenced the regulatory output, it is still evident that the student permanence issue was constructed as part of the broader debate about affirmative action. Documents and interviews that constitute the database for this study do not provide as much indication that the output was shaped by narratives as the other cases. Nevertheless, the institutional reference that affirmative action policies constitute a wide process within the University corroborates that UFPEL's affirmative action policies are subject to a policy process of greater scope than simply implementing the system demanded by law. It also brings to light that the affirmative action issue permeates different institutional spaces. According to agenda setting literature, processual settings such as this are populated by storytelling and the NPF offers potential of innovation by presenting empirical tools for analysis of these stories. We hope we were able to introduce this framework's theory and provide a meaningful example of its application to an empirical object.

\section{CONCLUSION}

Central questions to this study revolved around the presence of policy narratives and their role in the policy process in analysis. Results and discussion indicate that stories utilized in the process fit into the "policy narrative" concept, as narrative components developed in NPF theory are present in the documents and interviews, and that these stories influenced consequent regulatory outputs.

The greatest contribution of this article is its effort to jumpstart NPF research in Brazil. This framework has been increasingly gathering attention of policy analysis scholars and presents interesting developments for policy research, supplying tools for both quantitative and qualitative research and providing practical means for empirical study of policy change. In the context of this special issue, NPF presents a practical way for specification of agenda setting concepts and provides scholars with a new approach to analyze narratives in an environment where post positivism has traditionally exercised a marked influence. Integration of quantitative and qualitative methods can help scholars analyze and search for comprehension of the role of the stories that run rampant in the modern world, both in politics and in general culture.

In a time of fake news and "post-truth", narratives are undoubtedly used as a powerful tool for political manipulation. Analyzing the construction and crafting of these narratives and the cognition processes that sustain them can be one of many ways in which science tries to understand worldwide movements that shook the political world in recent years and impacted policy making as well. Prior to undertaking these broader goals though, NPF must be properly introduced and tested in different settings, as to establish its role as an effective tool to analyze narratives across geographic, institutional and socioeconomic spaces. If NPF's claims of transferability and generalizability are to be confirmed, then its application across different settings must be supported, which is what we set out to test and discuss in this article.

Perhaps most important for scientific validation, we dedicated special attention to following the guidelines of qualitative research trustworthiness - credibility, transferability, dependability and confirmability. We understand this study is in accordance with these standards as it uses data that was previously validated in the academic field and applies methodology similar to other NPF studies such as O'Leary et al. (2014). 
A possible limitation of the article is that due to research design choices, data is not presented more systematically. This is the case because presenting an overview of NPF and specifying combining aspects with agenda setting literature was as crucial to the study as its empirical research. We look forward to producing both qualitative and quantitative NPF studies in the future, analyzing policy making in other settings and exploring further intersection with agenda setting theory. 


\section{REFERENCES}

Ávila, C. S., \& Oliveira, W. J. F. (2009). Negros em movimento, o movimento dos negros. A mobilização negra em Pelotas 1987-2007. In Anais do $27^{\circ}$ Congreso de la asociación latinoamericana de sociologia, Buenos Aires, Argentina.

Baumgartner, F. R., \& Jones, B. D. (1993). Agendas and instability in American politics. Chicago, IL: University of Chicago Press.

Beach, B., \& Pedersen, R. B. (2016). Causal study methods: Foundations and guidelines for comparing, matching and tracing. Ann Arbor: Michigan University Press.

Bozeman, B. (2013). What organization theorists and public policy researchers can learn from one another: Publicness Theory as a case-in-point. Organization Studies, 34(2), 169-188.

Cardoso, F. H. (2003). Capitalismo e escravidão no Brasilmeridional: O negro na sociedade escravocrata do Rio Grande do Sul (5. Ed.) Rio de Janeiro, RJ: Civilização Brasileira.

Fischer, F. (2003). Reframing public policy: Discursive politics and deliberative practices. New York, NY: Oxford University Press.

Fischer, F. (2006). Deliberative policy analysis as practical reason: Integrating empirical and normative arguments In F. Fischer, G. J. Miller, \& M. S. Sidney. (Eds.), Handbook of Public Policy Analysys: Theory, politics and methods (pp. 223-236). Boca Raton, FL: CRC Press.

Fischer, F., \& Forester, J. (Eds.) (1993). The argumentative turn in policy analysis and planning. Durham, NC: Duke University Press.

George, A., \& Bennet, G. (2005). Case study and theory development in the Social Sciences, Cambridge: MIT Press.

Gray, G., \& Jones, M. D. (2016). A qualitative narrative policy framework? Examining the policy narratives of US campaign finance regulatory reform. Public Policy and Administration, 31(3), 193-220.

Jones, M. D. (2018). Advancing the Narrative Policy Framework? The Musings of a Potentially Unreliable Narrator. Policy Studies Journal, 46(4), 724-746.
Jones, M. D., \& McBeth, M. K. (2010). A Narrative Policy Framework: Clear enough to bewrong? Policy Studies Journal, 38(2), 329-353.

Jones, M. D., \& Radaelli, C. M. (2015). The Narrative Policy Framework: Child or monster? Critical Studies Journal, 9(3), 339-355.

Hajer, M. A. (1993). Discourse coalitions and the institutionalization of practice: The case of acid rain in Britain. In F. Fischer, J. Forester. (Eds.), The argumentative turn in policy analysis and planning (pp. 43-76). Durham, NC: Duke University Press.

Kingdon, J. W. (2014). Agendas, alternatives, and public policies. Melbourne, Australia: Pearson New International Edition.

Kirkpatrick, K. J., \&Stoutenborough, J. W. (2018). Strategy, narratives and reading he public: Developing a micro-level theory of political strategies within the Narrative Policy Framework. Policy Studies Journal, 46(4), 949-977.

Lima, M. (2010). Desigualdades raciais e políticas públicas: Ações afirmativas no governo Lula. Novos estudos - CEBRAP, 29(2), 77-95.

Majone, G. (1989). Evidence, argument and persuasion in the policy process. New Haven, CT: Yale University Press.

March, J. G. \& Simon, H. (1958). Organizations. New York, NY: Wiley.

Ney, S. (2014). The governance of social innovation: Connecting meso and macro level of analysis. In $\mathrm{M}$. D. Jones, E. A. Shanahan, \& M. K. McBeth. (Eds.) The science of stories: Applications of the Narrative Policy Framework in Public Policy Analysis (pp. 207-234). New York, NY: Palgrave Macmillan.

Nunes, G. H. L. (2018). Autodeclarações e comissões: Responsabilidade procedimental $\mathrm{dos} / \mathrm{as}$ gestores/as de ações afirmativas. In G. R. M. Dias, \& P. R. F. Tavares, Jr. (Orgs.), Heteroidentificação e cotas raciais: Dúvidas, metodologias e procedimentos. Canoas, RS: Instituto Federal Rio Grande do Sul.

O'Leary, R., Borland, R., Stockwell, T., \&MacDonald, M. (2017). Claims in vapour device (e-cigarette) regulation: A Narrative Policy Framework analysis. International Journal Of Drug Policy, 44, 31-40. 
Peterson, H. L. (2018). Political information has bright colors: Narrative Attention Theory. Policy Studies Journal, 46(4), 828-842.

Peterson, H. L., \& Jones, M. D. (2016). Making sense of complexity: The narrative policy framework and agenda setting. In N. Zahariadis. (Ed.), Handbook of public policy agenda setting. Cheltenham, UK: Edward Elgar Publishing.

Rochefort, D. A., \& Cobb, R. W. (Eds.) (1994). The politics of problem definition: Shaping the policy agenda. Lawrence, KS: University Press of Kansas.

Rodrigues, D. D., Neto. (2018). Formação de agenda em uma universidade pública: A construção da questão das ações afirmativas. Universidade Federal de Pelotas, Pelotas, RS.

Rodrigues, D. D., Neto, Barcelos, M. \& Pinto, R. S. (2019) Construção de problemas públicos e processos de tomada de decisão: Uma tentative de diálogo entre Análise de Políticas Públicas e Teorias Organizacionais. In Anais do $22^{\circ}$ Seminários em Administração, São Paulo, SP.

Rosa, R. R. G., Nunes, G. H. L., \& Larré, R. B. (2017) As Ações Afirmativas na Universidade Federal de Pelotas: Políticas públicas, institucionalização e democratização da educação superior. In D. Mato. (Org.), Educación superior y pueblos indigenas y afrodescendientes en América Latina: Politicas y prácticas de inclusión, democratización e interculturalización. Buenos Aires, Argentina: Eduntref.

Santos, A. P. (2012). Itinerário das ações afirmativas no ensino superior público brasileiro: Dos ecos de Durban à lei das cotas. Revista de CiênciasHumanas, 8(2), 289-317.

Schattschneider, E. E. (1960). The semi-sovereign people: A realist's view of democracy in America. Hirsdale, IL: The Dryden Press.

Shanahan, E. A., Adams, S. M., Jones, M. D., \& McBeth, M. K. (2014). The blame game: Narrative persuasiveness of the intentional cause mechanism. In M. D. Jones, E. A. Shanahan, \& M. K. McBeth.
(Eds.), The science of stories: Applications of the Narrative Policy Framework in Public Policy Analysis (pp. 69-88). New York, NY: Palgrave Macmillan.

Shanahan, E. A., Jones, M. D., \& McBeth, M. K. (2018). How to conduct a Narrative Policy Framework study. The Social Science Journal, 55, 332-345.

Shanahan, E. A., Jones, M. D., McBeth, M. K., \& Lane, R. R. (2013). An angel on the wind: How heroic policy narratives shape policy realities. Policy Studies Journal, 41(3), 453-483.

Shanahan, E. A., Raile, E. D., French, K. A., \& McEvoy, J. (2018). Bounded stories. Policy Studies Journal, 46(4), 922-948.

Simon, H. (1979) Comportamento administrativo: Estudo dos processos decisórios nas organizações administrativas (3. Ed.). Rio de Janeiro, RJ: Fundação Getulio Vargas.

Stone, D. (1989). Causal stories and the formation of policy agendas. Political Science Quarterly, 104(2), 281-300.

Stone, D. (2012). Policy paradox: The art of political decision making. New York, NY: WW Norton.

Weible, C. M., \& Carter, D. P. (2017) Advancing Policy Process Research at Its Overlap with Public Management Scholarship and Nonprofit and Voluntary Action Studies. Policy Studies Journal, 45(1), 22-49.

Weible, C. M., \& Schlager, E. (2014). Narrative Policy Framework: Contributions, limitations, and recommendations. In M. D. Jones, E. A. Shanahan, \& M. K. McBeth. (Eds.), The science of stories: Applications of the Narrative Policy Framework in Public Policy Analysis (pp. 235-246). New York, NY: Palgrave Macmillan.

Zanocco, C., Song, G., \&Jones, M. (2018). Fracking bad guys: The role of narrative characters affect in shaping hydraulic fracturing policy preferences. PolicyStudiesJournal, 46(4), 978-999. 
RAP | Stories in the agenda: a Narrative Policy Framework study

\section{Damasio Duval Rodrigues Neto}

https://orcid.org/0000-0001-9993-7028

Master in Public Administration. E-mail: damasio.rodrigues@gmail.com

\section{Márcio Barcelos}

https://orcid.org/0000-0003-3205-1673

Ph.D. in Sociology; Professor in the Department of Administration at the Faculty of Administration and Tourism of the Federal University of Pelotas (UFPEL FAT).E-mail: barcelosmarcio@gmail.com 